\title{
Hydrogen mixture with gasoline for conventional motorcycles and effect on mass flow rate, brake thermal efficiency and emissions
}

\author{
H. Razali ${ }^{1 *}$, K. Sopian ${ }^{1}$, S. Mat ${ }^{1}$, M.R.A. Mansor ${ }^{2}$ and N. Amon ${ }^{3}$ \\ ${ }^{1}$ Solar Energy Research Institute, National University of Malaysia, \\ 43600 Bangi, Selangor, Malaysia \\ ${ }^{2}$ Faculty of Engineering and Build Environment, National University of Malaysia, \\ 43600 Bangi, Selangor, Malaysia \\ ${ }^{3}$ Mechanical Engineering Department, Port Dickson Polytechnic, \\ 71050 Port Dickson, Negeri Sembilan, Malaysia \\ *Email: drhalimrazali@ukm.edu.my
}

\begin{abstract}
The fossil fuel price crisis and emissions control in the transportation sector in Malaysia have become national issues, especially in the transportation sector. As an alternative, using hydrogen mixed with gasoline fuel in conventional combustion engines is a very effective way of improving engine performance and emission control. Generating hydrogen via a chemical reaction between hydrochloric acid and aluminium is a new approach in this study. This methodology has been tested through the mixture application $\left(\mathrm{G}+\mathrm{H}_{2}\right)$ in 10-year-old motorcycles (gasoline) with a modified conventional carburettor engine. The testing of engine performance by chassis dynamometer was done at three levels of experiments: L0: 0 Amp load, L1: 1 Amp load, and L2: 2 Amp load for different engine performances, particularly in identifying quality improvements through the brake thermal efficiency. The study found that the average increase in brake thermal efficiency was $23 \%$ higher in the $\left(\mathrm{G}+\mathrm{H}_{2}\right)$ engine compared to gasoline only. The results of this study have proven that the use of hydrogen $(\mathrm{Al}+\mathrm{HCl})$ in the stoichiometric ratio has helped to increase combustion efficiency, especially when the oxygen content in the fuel mixture ratio is not adequate during the stroke of power. The successful reduction in fuel consumption, increased engine performance, reduction of pollution and the system's ability to meet the basic needs of the internal combustion engine cycle can be beneficial to the development of the automotive industry, particularly in the transport sector.
\end{abstract}

Keywords: Hydrogen; Chemical reaction; Alternative Fuel; Mass flow rate; Brake thermal efficiency.

\section{INTRODUCTION}

The number of motorcycles registered in 2013 reached 528,508 units in Malaysia [1]. The rising motorcycle utilisation every year contributes to global pollutants, especially from vehicles that are still using the carburettor system [1]. A motorcycle engine operates by applying atmospheric pressure to convert liquid fuel to vapour in the carburettor system. Atmospheric pressure of around $6.8 \mathrm{~kg}$ per square inch (psi) causes pressure reduction in the carburettor when the piston starts moving down (BDC) [2]. As a result, this movement causes pressure differentials, and this allows air to enter the combustion chamber into the cylinder until the pressure in the two halves becomes equal [3]. The high airflow through the carburettor will cause fuel to flow out into the venturi and mix with air by gravity. 
This process occurs when the atmospheric pressure is lowered (down) and the air flow velocity increases through the carburettor, as shown in Figure 1. The needle on the carburettor jet plays an important role in controlling the flow of fuel into the carburettor venturi. The mass flow rate of gasoline fuel will increase when the valve is open, thus draining the little pen air flow $\left(\mathrm{O}_{2}\right)$ into the carburettor circuits and producing a varying mixture of air and fuel. There are two states of fuel mixture (rich, lean) of air and fuel that determine the performance of the engine between the stoichiometric mixture, i.e. the ratio of the mixture of air/fuel close to $14.7: 1$ or 15:1 [4]. This means that the ratio of the air/fuel mixture is sufficient for complete combustion. In the rich mixture condition, the amount of air is less than the fuel mixture $\left(\mathrm{O}_{2}<\right.$ fuel $)$, which is below the ideal mixture ratio of 12:1. The lean mixture is a condition when the ratio is above $16: 1\left(\mathrm{O}_{2}>\right.$ fuel $)$ [5, 6]. Based on the two situations of fuel mixtures, the lean and rich conditions produced problems in the quality of combustion efficiency and pollution issues [6]. An imbalanced mixture between fuel and air via the process of condensation on the carburettor system will have a negative impact on the combustion performance and pollution [7].

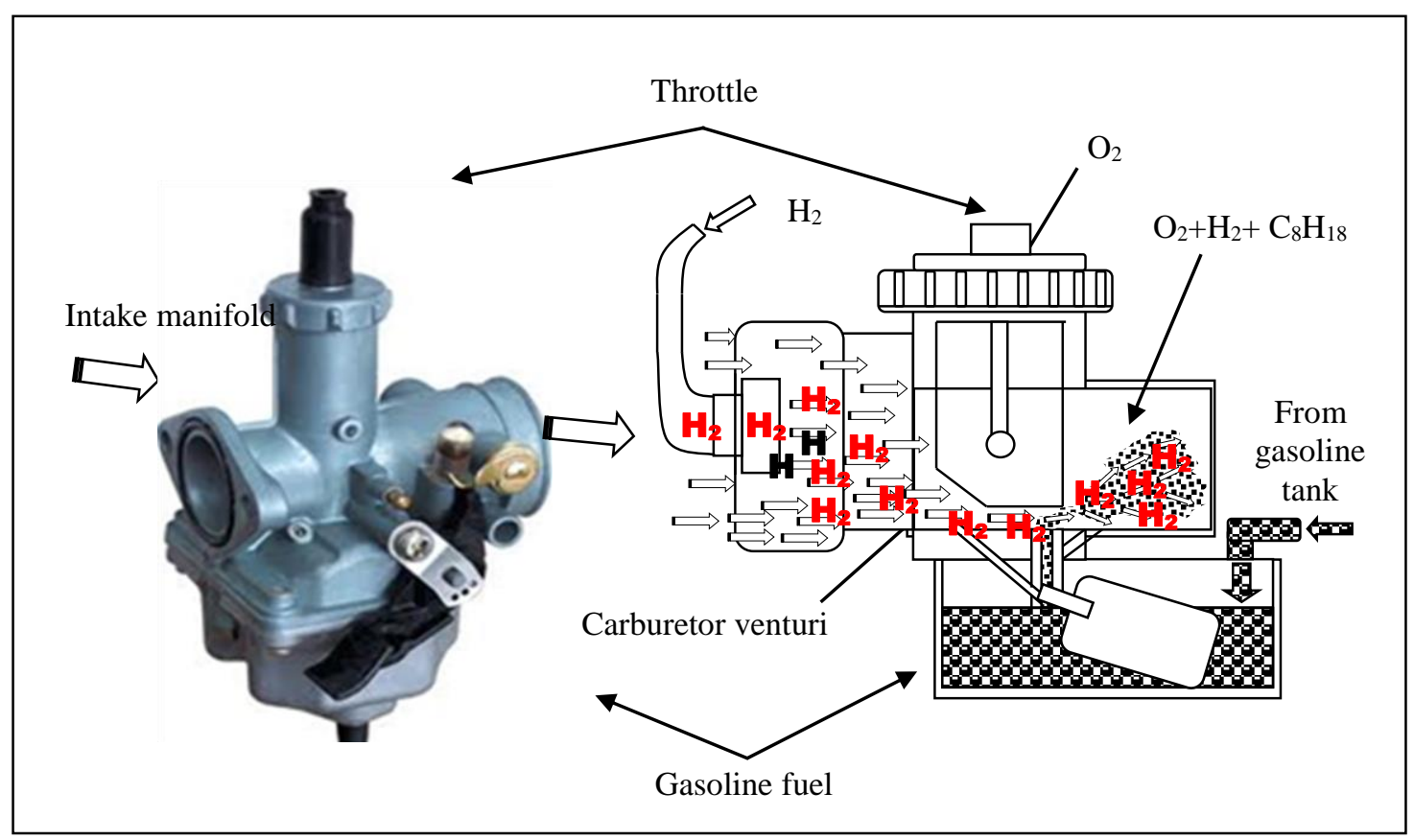

Figure 1. Schematic diagram of flow mixtures in the conventional carburettor engine.

Gas pollutants such as hydrocarbon (HC) and carbon monoxide (CO) is a side product from the incomplete combustion of the mixture of fuel and compressed air in the combustion chamber and is related to the brake thermal efficiency. Combustion imperfections are often caused by lack of oxygen in the fuel compression ratio [5]. The oxidation of carbon atoms in the fuel (gasoline) to carbon dioxide $\left(\mathrm{CO}_{2}\right)$ cannot be completes owing to a lack of oxygen atoms. Creep fire from the spark plug also cannot reach the full space of the combustion chamber owing to a lack of oxygen to support combustion [3]. This often happens when the engine temperature is below the working temperature $\left(80^{\circ} \mathrm{C}\right)$, especially when starting the engine and then heating it up in the cold condition. Initial operation of the engine in the morning with humid temperatures causes a higher production of $\mathrm{HC}$ and $\mathrm{CO}$ than normal [7]. Apart from the incomplete combustion, the existence of $\mathrm{HC}$ and $\mathrm{CO}$ and engine temperature, other factors such as the occurrence of a leak in the carburettor or injector, the fuel pressure being too high 
making it difficult for fuel oxidation with oxygen, as well as very high engine temperature also affect the presence of $\mathrm{CO}$ [8]. When the engine temperature is too high it will eliminate water $\left(\mathrm{H}_{2} \mathrm{O}\right)$ and the entry of oxygen into the combustion chamber becomes unbalanced, $\mathrm{HC}, \mathrm{CO}$ and $\mathrm{NOx}$ will be generated as poisonous gases [9]. With regards to the problems mentioned above, utilisation of hydrogen as a supplementary fuel can improve and increase the combustion efficiency and solve this issue as the best solution [10]. It is because the addition of hydrogen in the gasoline fuel (in a carburettor system) can have a positive impact on the efficiency of combustion (complete combustion). At the same time, the brake thermal efficiency will also increase [11]. The phenomenon is related to the condition of the mixed ratio of fuel through the mass flow rate in $\mathrm{kg} / \mathrm{s}$. This condition is expressed in Figure 1, which displays the difference between the mass flow rate $(\mathrm{mf})$ for the use of gasoline fuel mixture with hydrogen $\left(\mathrm{G}+\mathrm{H}_{2}\right)$ and gasoline $(\mathrm{G})$ as the main fuel.

In this study, the use of hydrogen generated via chemical reaction between aluminium and hydrochloric acid as an alternative fuel was investigated. The identified quality improvement was tested by chassis dynamometer through the brake thermal efficiency, reduction of hydrocarbon and carbon monoxide differences in the internal combustion engine at three levels of load condition: (L0 = $0 \mathrm{Amp})$, load 1 ( L1 = $1 \mathrm{Amp})$ and load 2 (L2 = 2 Amp) for different engine parameter performances. The results of this study show the changes to engine performance from using the hydrogen mixture $\left(\mathrm{G}+\mathrm{H}_{2}\right)$, the reduction of pollution and the system's ability to meet the basic needs of the internal combustion engine especially for 10 year-or-more-old motorcycles

\section{METHODS AND MATERIALS}

\section{Production of Hydrogen Through Chemical Reaction}

The chemical reaction rates in the experiment are capable of predicting the performance of the reaction based on the concentrations of reactants, reactant mass changes, colour changes during the reaction, acidity changes during the reaction, and changes in sediment concentration produced $[12,13]$. Through the changes that occurred, graphs of the reaction could be produced, as shown in Figure 2. Referring to the red line, Figure 2 shows the ability of a chemical process to produce hydrogen gas. The intensity of the reaction can be determined and controlled by the concentration of acid used, the temperature during the process, the particle surface area involved and the design of the catalyst used. It can determine the quantity of hydrogen produced in $\mathrm{cm}^{3}$ versus time. Pure hydrogen production can also be seen to be reduced when the graph becomes static and constant.

\section{Interpretation of Reaction Rates}

The rate of a chemical process can be classified based on three conditions. The changes in quantity of material produced, gas volume and mass used are observed to calculate the reaction rate for production of moles of hydrogen [14]. The occurrence of these three conditions depends on the amount of time required for the chemical process, either by looking for changes in the product yields or properties of the elements resulting from the reaction process [15]. Any interpretation of the reaction rate can be more easily understood with reference to the conditions a, b and c, and by referring to Eqs. (1), (2) and ( 3 ) as follows:

Condition a: Reaction that occurs in the material:

$$
R r=\frac{\text { Changes in the quality of the product from the reaction }}{\text { Total time of reaction }}
$$




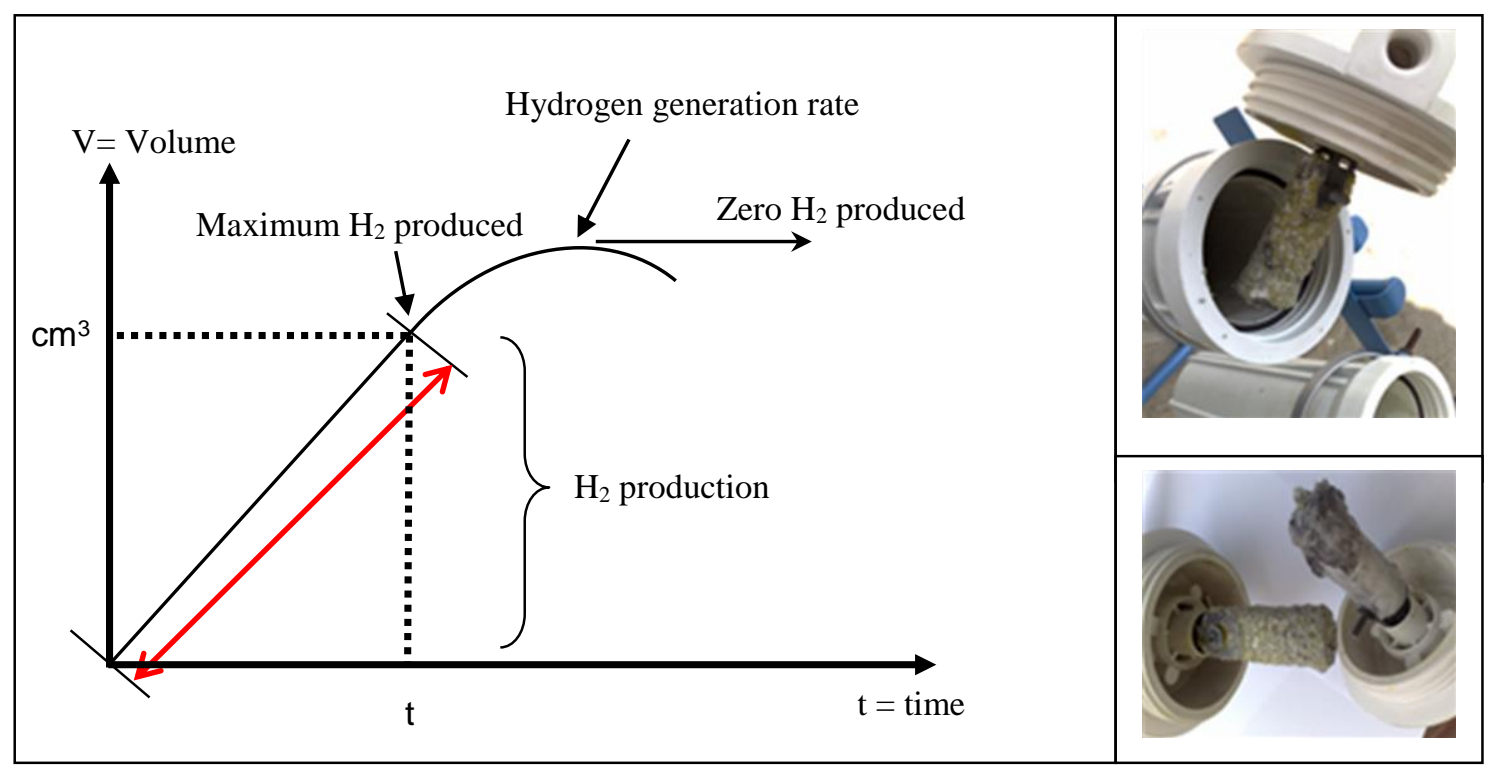

Figure 2. Production rate of hydrogen through a chemical reaction between aluminium (Al) and acid hydrochloric acid $(\mathrm{HCl})$.

Condition b: Reaction of gases:

$$
R r=\frac{\text { Volume of gas released }}{\text { Total time of reaction }}
$$

Condition c: Reaction involving mass to be considered:

$$
R r=\frac{\text { Mass of the material used }}{\text { Total time of reaction }}
$$

Note* $\mathrm{Rr}=$ Reaction rate

The chemical reaction can be estimated when aluminium reacts with hydrochloric acid as shown in the chemical equation below:

$$
\mathrm{Al} \text { (solid) }+2 \mathrm{HCl} \text { (Liquid) } \longrightarrow \mathrm{AlCl} \text { (Alkaline) }+\mathrm{H}_{2} \text { (Gaseous) }
$$

Through observation of the reaction process, the mass of $\mathrm{Al}$ will be reduced, as shown by the mass and time readings taken during the experiments. The experiment in this study followed the steps shown in Table 1. The formula for the reaction rate can be expressed in two units: aluminium per mass/time and mol/time [2]. The rate of the reaction between $\mathrm{Al}$ and acid will determine the production of hydrogen gas [16]. When this process continues, the volume of hydrogen gas will increase with time. Thus the assumption of hydrogen gas volume produced/accumulated will be the unit of time $t=y$ $\mathrm{cm}^{3}$ and the average rate of reaction of hydrogen gas is $\mathrm{y}=$ volume/time or by using the $\mathrm{y} \mathrm{cm}^{3}=$ piston syringe [3]. 
Table 1. Experimental procedure.

\begin{tabular}{lc}
\hline \multicolumn{1}{c}{ Experimental steps } & Measurement parameters \\
\hline 1. Original mass of aluminium (Al) & A gram \\
2. Mass of Al after reaction. & $\mathrm{B}$ gram \\
3. The total mass that has been used. & $(\mathrm{A}-\mathrm{B})$ gram \\
4. The average reaction time. & $\mathrm{t}(\mathrm{second})$ \\
5. The average rate of reaction. & $(\mathrm{A}-\mathrm{B}) / \mathrm{t}$ \\
6. Determine the relative atomic mass of $\mathrm{Al}$. & $26.981538 \mathrm{~g} / \mathrm{mole}$ \\
7. Number of moles of $\mathrm{Al}$ used in $(\mathrm{t})$ seconds. & $\mathrm{t}=(\mathrm{A}-\mathrm{B}) / \mathrm{relative}$ atomic mass \\
8. Average rate of reaction. & moles $/$ time \\
\hline
\end{tabular}

\section{Hydrogen Generation and Testing}

Hydrogen is produced through the reaction of aluminium with hydrochloric acid. The presence of air $\left(\mathrm{O}_{2}\right)$ and water $\left(\mathrm{H}_{2} \mathrm{O}\right)$ will produce wet hydrogen. The hydrogen gas produced from the chemical reaction prosess $(\mathrm{Al}+\mathrm{HCl}-$ Reaction Unit as an onboard generation) to transferred into the cylinder tube and compressed by a vacuum pump before the pressurised hydrogen is released by pressure regulator unit into the ICE combustion chamber. Figure 3 illustrates a conventional motorcycle before and after modification. It shows how the experiment uses the hydrogen generation model through a chemical reaction between acid and metal to produce hydrogen gas as an alternative energy source for spark ignition engines (motorcycles). As gasoline is the existing fuel in currently available motorcycles, these models are operated on board and act as an energy source or alternative fuel by blending hydrogen with gasoline $\left(\mathrm{G}+\mathrm{H}_{2}\right)$.

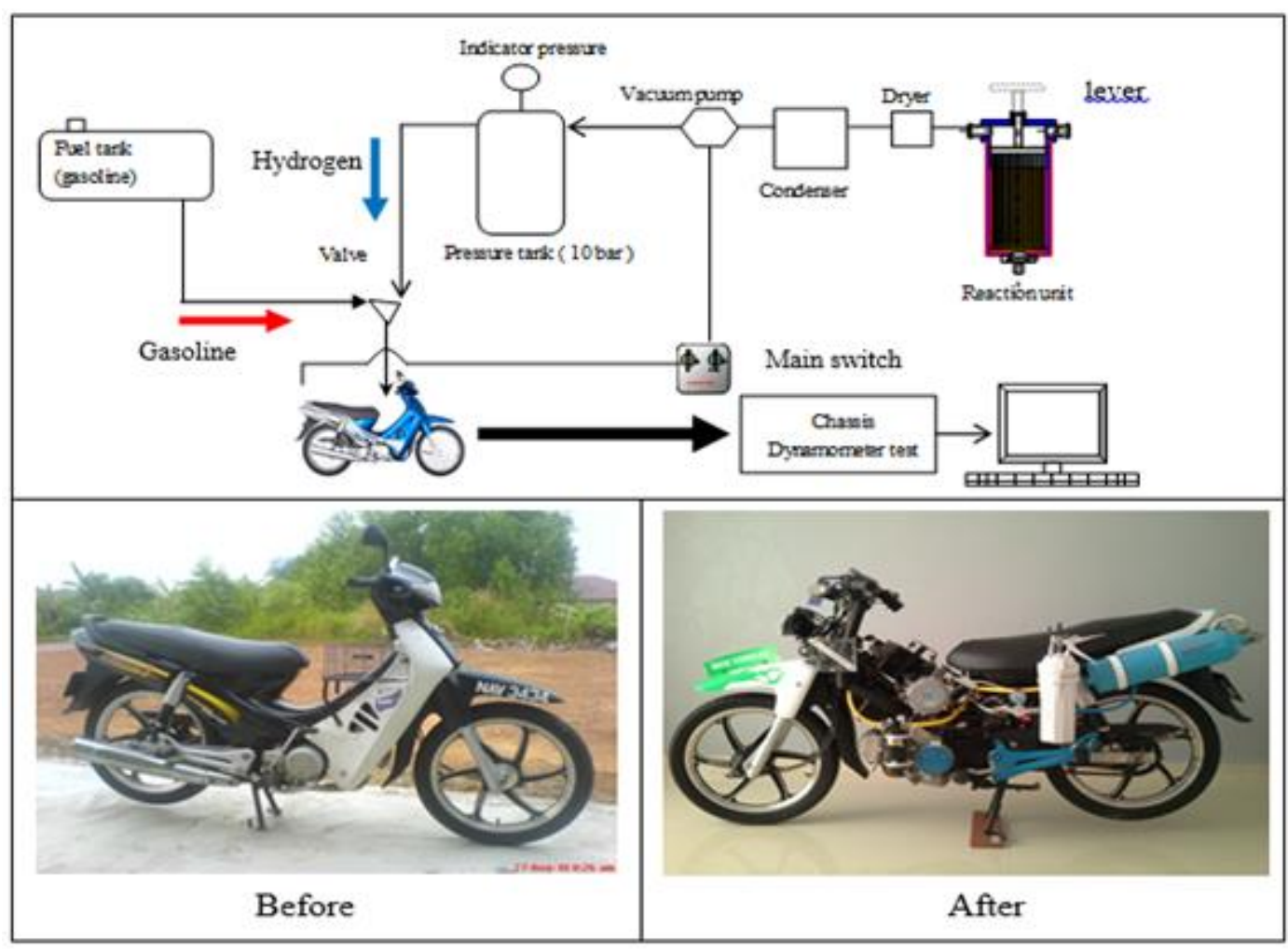

Figure 3. Conventional motorcycle before and after and the addition of onboard hydrogen production system. 
The selection of the fuel-based energy source or blended fuel $\left(\mathrm{G}+\mathrm{H}_{2}\right)$ is controlled by valve control switch options. The system operates with two main switches. The first switch serves to activate the circuit for the magneto ignition system (spark plug), and the second switch activates the pressure regulator and vacuum pump. At the same time, an aluminium sheet is passed through the catalyst lever either manually or automatically to produce hydrogen. Figure 4 shows the testing of the hydrogen motorcycle to compare the performance of engine $\left(\mathrm{G}+\mathrm{H}_{2}\right)$ with engine $(\mathrm{G})$ through the load tests L0, L1 and L2. The definitions for the level test load are: L1: engine movement at maximum speed through hilly terrain or at 1 ampere load. L2: engine moving at maximum speed through hilly terrain or at 2 ampere load (the chassis dynamometer test specifications that use DC Karan is equal to L0 $=0$ Ampere, L1 $=1$ Ampere, L2 $=2$ Ampere).

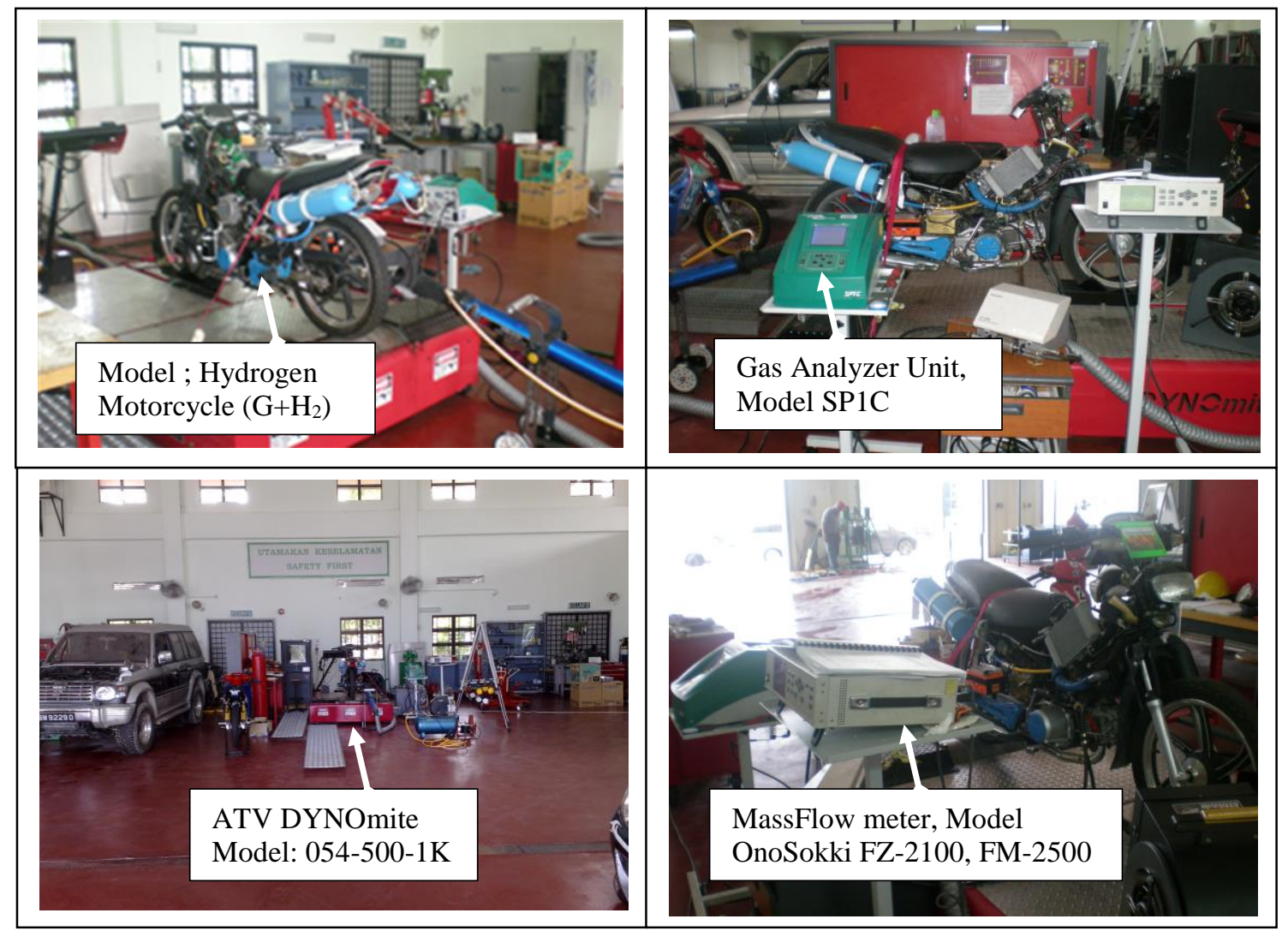

Figure 4. The testing of the hydrogen motorcycle to analyse the performance of engine $\left(\mathrm{G}+\mathrm{H}_{2}\right)$ and engine $(\mathrm{G})$ through the load test L0-0 Amp, L1-1 Amp, and L2-2 Amp.

\section{RESULTS AND DISCUSSION}

This section will discuss the results in connection with the experiments that have been conducted regarding the differences of mass flow rate value (mf) and brake thermal efficiency for gasoline and hydrogen fuel mixture $\left(\mathrm{G}+\mathrm{H}_{2}\right)$ and gasoline $(\mathrm{g})$. Table 2 shows the reduction in mass flow (mf) for the engine with $\mathrm{G}+\mathrm{H}_{2}$ as compared to the engine with $\mathrm{G}$ at maximum engine speed (full throttle), $\mathrm{ig}=3.0$ (4th gear), at $\mathrm{t}=6$ seconds and maximum $\mathrm{T}(\mathrm{Nm})$. The average flow rate of gasoline fuel can be monitored while the motorcycle is moving at maximum speed without load (L0). The mass flow rate of the $G$ 
$+\mathrm{H}_{2}$ decreased by $9 \%$ from $5: 44 \times 10^{-4} \mathrm{~kg} / \mathrm{s}$ for $\mathrm{G}$ to $4.97 \times 10^{-4} \mathrm{~kg} / \mathrm{s}$ for the $\mathrm{G}+\mathrm{H}_{2}$. The results showed that the mass flow rate increased by $17 \%$ and $21 \%$ when the engine was moving at maximum speed in load test L2. This is important because when the engine is moving slowly because of resistance, the mf is reduced because of the effect of the reduction of vacuum as a result of the slow rotation of the piston in the cylinder. In this situation, hydrogen was used as a supplementary fuel to increase the combustion efficiency for the engine performance and to reduce the fuel consumption. Overall reduction of the mass flow rate in the three conditions (L0, L1, L2) was $15 \%$ when compared to the mf for normal engine operation $(\mathrm{G})$. This result suggests that the addition of hydrogen in the mixture of fuel/air $\left(\mathrm{O}_{2}+\mathrm{H}_{2}+\right.$ gasoline $)$ can lower the mass flow rate (mf) by helping the combustion process. The involvement of hydrogen in the stoichiometric mixture ratio can increase the quality of combustion and reduce the factor of energy losses via technical influences such as friction in the cylinder walls, rich and poor mixtures, and ignition failure (misfire) [17]. Table 3 shows that the efficiency of engine performance and emission control improved, although the resistance movement in various conditions can reduce the specific fuel consumption, increase the brake thermal efficiency on the power stroke and reduce the emissions of hydrocarbon and carbon monoxide. In this case, hydrogen improves the performance of combustion by helping to ensure complete combustion despite a poor oxygen mixture ratio in the oxidation of hydrocarbon fuels [10].

Table 2. The differences in the average mass flow rate $(\mathrm{mf})$ for the mixture of gasoline and hydrogen $\left(\mathrm{G}+\mathrm{H}_{2}\right)$ and gasoline only $(\mathrm{G})$.

$\mathrm{mf}(\mathrm{kg} / \mathrm{s})$ full throttle, Gear ratio $(\mathrm{ig})=3.0($ gear 4$), \mathrm{t}=6$ seconds at engine torque $(\mathrm{T})$ maximum $(\mathrm{Nm})$

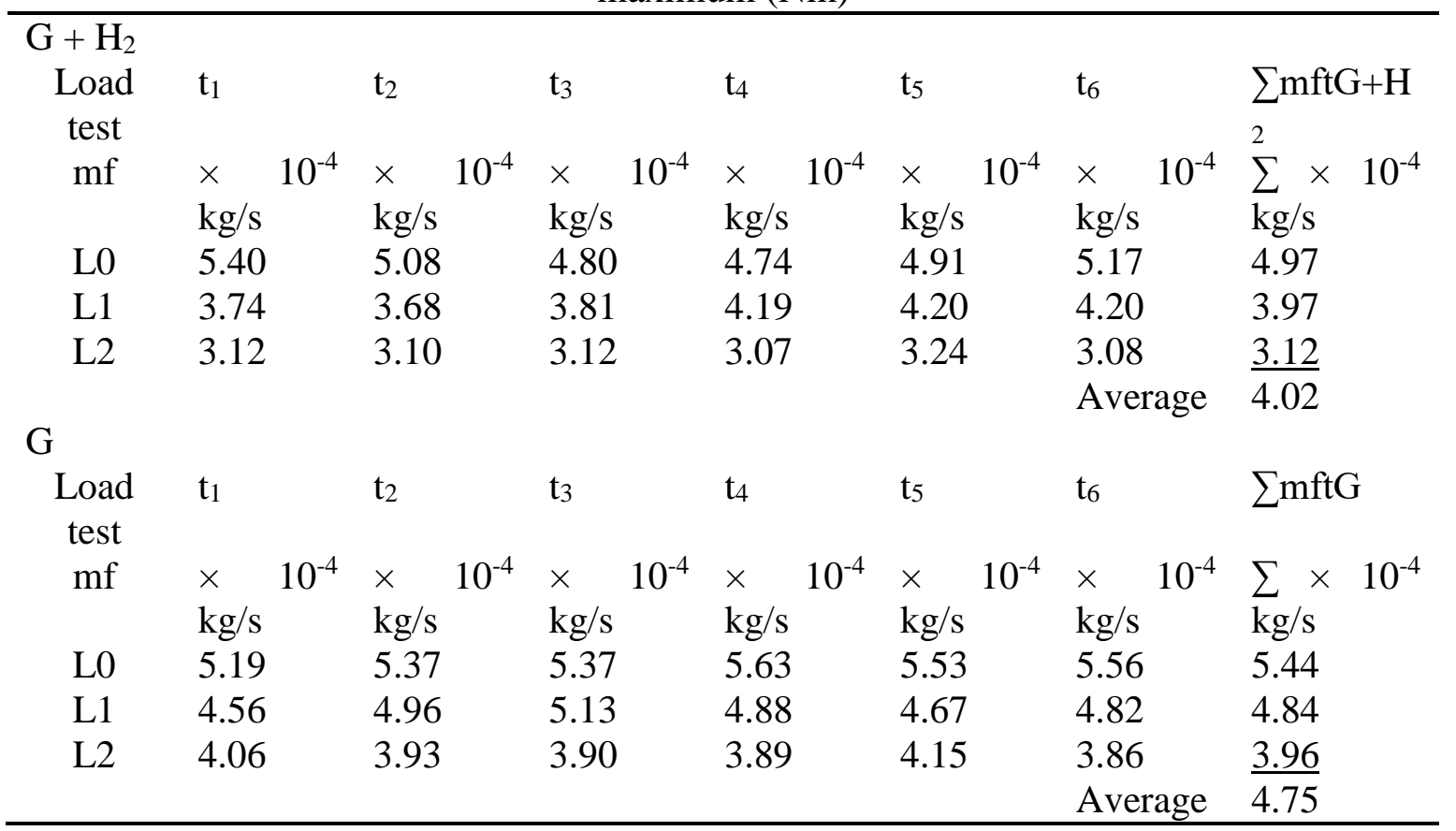


Table 3. Effects of hydrogen in the air fuel mixture and combustion efficiency.

\begin{tabular}{|c|c|c|c|c|}
\hline $\begin{array}{l}\text { Para- } \\
\text { meter }\end{array}$ & $\begin{array}{l}\text { Results } \\
\text { (L0, L1, L2) }\end{array}$ & $\begin{array}{l}\text { Average value } \\
\text { from this study }\end{array}$ & $\begin{array}{c}\text { Comparisons } \\
\text { data }\end{array}$ & References \\
\hline Sfc & $\begin{array}{l}\left(\mathrm{G}+\mathrm{H}_{2}\right)= \\
98 \mathrm{~g} / \mathrm{kwh} \\
(\mathrm{G})=123 \\
\mathrm{~g} / \mathrm{kwh}\end{array}$ & $-20.3 \%$ & $\begin{array}{c}-12 \% \\
-33.25 \% \\
(-) 24 \% \text { to } 34 \% \\
-33 \%\end{array}$ & $\begin{array}{l}\text { M.Akif Ceviz (2012) } \\
\text { Changwei Ji \& Shuo } \\
\text { Feng wang (2012) } \\
\text { D’Sainz et.al (2011) } \\
\text { Yu Chao et.al (2009) }\end{array}$ \\
\hline$\eta b t$ & $\begin{array}{l}\left(\mathrm{G}+\mathrm{H}_{2}\right)= \\
8.61 \% \\
(\mathrm{G})=7 \%\end{array}$ & $+23 \%$ & $\begin{array}{l}13.81 \% \text { to } \\
20.20 \% \\
\\
+18 \% \\
+5 \% \\
+12.9 \%\end{array}$ & $\begin{array}{l}\text { Changwei Ji \& Shuo } \\
\text { Feng wang (2010) } \\
\text { M.Akif Ceviz (2012) } \\
\text { Maher (2000) } \\
\text { Probir kumar (2009) }\end{array}$ \\
\hline $\mathrm{HC}$ & $\begin{array}{l}\mathrm{L} 0=-58.2 \% \\
\mathrm{~L} 1=-27.4 \% \\
\mathrm{~L} 2=-16.7 \%\end{array}$ & $-34.1 \%$ & $\begin{array}{c}21 \% \\
25 \% \text { to } 40 \% \\
76.44 \% \\
13 \% \text { to } 20 \%\end{array}$ & $\begin{array}{l}\text { Yu Chao et.al (2009) } \\
\text { Zuo Yu Sun et.al } \\
\text { (2012) } \\
\text { Changwei Ji \& Shuo } \\
\text { Feng Wang (2010) } \\
\text { M.Akif Ceviz (2012) }\end{array}$ \\
\hline $\mathrm{CO}$ & $\begin{array}{l}\mathrm{L} 0=-41.1 \% \\
\mathrm{~L} 1=-12.6 \% \\
\mathrm{~L} 2=-45.2 \%\end{array}$ & $-33 \%$ & $\begin{array}{c}77 \% \text { to } 95 \% \\
89 \% \\
42 \%\end{array}$ & $\begin{array}{l}\text { Zuo Yu Sun et.al } \\
\text { (2012) } \\
\text { M.Akif Ceviz (2012) } \\
\text { Yu Chao et.al (2009) }\end{array}$ \\
\hline
\end{tabular}

Sources: M.Akif Ceviz (2012) Changwei Ji \& Shuo Feng wang (2012)[18], D’Sainz et al. (2011) Yu Chao et.al (2009), Maher (2000) [19], Changwei Ji \& Shuo Feng wang (2010) [20], Probir kumar (2009) [21, 22].

\section{Consideration of Mass Flow Rate and Brake Thermal Efficiency with Hydrogen as a Supplementary Fuel}

Brake thermal efficiency and mass flow rate are two of the main parameters to increase the quality of combustion. This consideration is related to the mixture ratio of fuel and air. Complete combustion provides the optimum amount of work that will produce the higher torque from the combustion process. The exchange of energy from the fuel is dependent on the quality of combustion. In reality, the air and fuel in the cylinder will not be able to combust completely. This is because there are several factors that influence incomplete combustion and energy will be lost from the engine work, especially the loss of heat through friction between the piston and the cylinder wall. Energy will be lost simultaneously through the flow of gas in the exhaust system, and the movement of the mechanical components, which require energy to move [10]. Indirectly, $60 \%$ to $65 \%$ of the energy produced by the combustion chamber (gasoline + air) in the cylinder will be lost before the balance is successfully transferred to the transmission system to produce force $(\mathrm{Fo})$ for vehicle movement. It is related to technical factors such as friction in the cylinder walls and the other mechanical components [17]. 
Table 4 display the brake thermal efficiency of the engine through three levels of engine load test: L0, L1 and L2. The average brake thermal efficiency ( $\eta b t)$ of the hydrogen engine $\left(\mathrm{G}+\mathrm{H}_{2}\right)$ and the gasoline engine $(\mathrm{G})$ was $8.61 \%$ and $7.0 \%$, respectively. The overall combustion efficiency for the hydrogen engine $\left(\mathrm{G}+\mathrm{H}_{2}\right)$ is $1.61 \%$ better than that for the gasoline engine $(G)$. In this situation, hydrogen gas is very flammable and can help to improve the quality of conventional combustion (gasoline engine).

Table 4. Brake thermal efficiency for $\mathrm{G}+\mathrm{H}_{2}$ and $\mathrm{G}$ based on L0, L1 and L2.

\begin{tabular}{|c|c|c|c|c|c|c|c|}
\hline \multicolumn{8}{|c|}{$\begin{array}{l}\eta \mathrm{bt}(\%) \text { full throttle, gear ratio }(\mathrm{ig})=3.0(\mathrm{gear} 4), \mathrm{t}=6 \text { second, at engine torque }(\mathrm{T}) \\
\text { maximum }(\mathrm{Nm})\end{array}$} \\
\hline \multicolumn{8}{|c|}{$\mathrm{G}+\mathrm{H}_{2}$} \\
\hline $\begin{array}{l}\text { Load test } \\
\text { L0 } \\
\text { L1 } \\
\text { L2 }\end{array}$ & $\begin{array}{l}\mathrm{t}_{1} \\
7.13 \\
9.01 \\
5.60\end{array}$ & $\begin{array}{l}\mathrm{t}_{2} \\
7.52 \\
9.81 \\
7.15\end{array}$ & $\begin{array}{l}t_{3} \\
8.60 \\
10.51 \\
7.61\end{array}$ & $\begin{array}{l}\mathrm{t}_{4} \\
9.30 \\
9.61 \\
8.25\end{array}$ & $\begin{array}{l}t_{5} \\
9.03 \\
10.77 \\
7.19\end{array}$ & $\begin{array}{l}\mathrm{t}_{6} \\
8.45 \\
10.83 \\
8.67 \\
\text { Average }\end{array}$ & $\begin{array}{c}\sum \eta b t G+H 2 \\
8.34 \\
10.09 \\
\underline{7.41} \\
8.61\end{array}$ \\
\hline \multicolumn{8}{|c|}{-5} \\
\hline $\begin{array}{l}\text { Load test } \\
\text { L0 } \\
\text { L1 } \\
\text { L2 }\end{array}$ & $\begin{array}{l}\mathrm{t}_{1} \\
6.93 \\
7.99 \\
6.52\end{array}$ & $\begin{array}{l}\mathrm{t}_{2} \\
7.33 \\
7.84 \\
5.69\end{array}$ & $\begin{array}{l}\mathrm{t}_{3} \\
8.00 \\
7.45 \\
5.91\end{array}$ & $\begin{array}{l}\mathrm{t}_{4} \\
7.87 \\
8.07 \\
5.17\end{array}$ & $\begin{array}{l}\mathrm{t}_{5} \\
7.81 \\
8.72 \\
3.98\end{array}$ & $\begin{array}{l}\mathrm{t}_{6} \\
7.77 \\
9.06 \\
3.86 \\
\text { Average }\end{array}$ & $\begin{array}{c}\sum \eta b t G \\
7.62 \\
8.19 \\
5.19 \\
7.00\end{array}$ \\
\hline
\end{tabular}

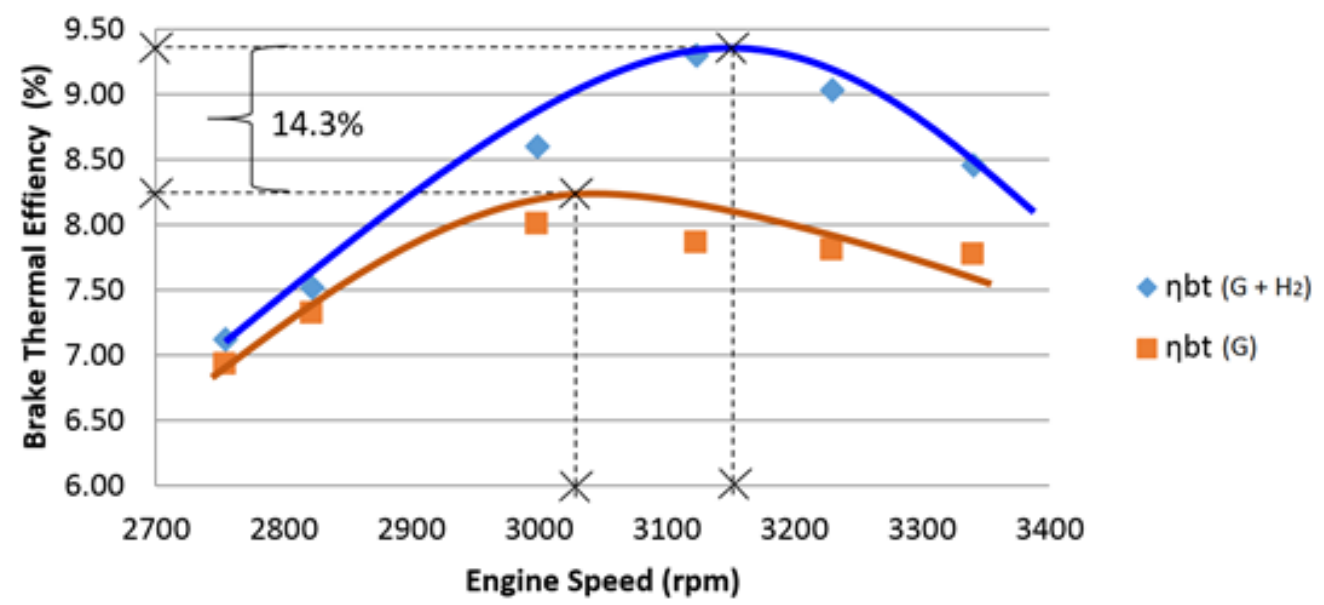

Figure 5. The differences of $\eta \mathrm{bt}$ for $\mathrm{G}+\mathrm{H}_{2}$ and $\mathrm{G}$ at test condition $\mathrm{L} 0$

Figure 5 Results for the engine in test condition L0, the brake thermal efficiency increases $14.3 \%$ for $\mathrm{G}+\mathrm{H}_{2}$ and at $9.50 \%$, the engine speed was higher at $3170 \mathrm{rpm}$ compared to $\mathrm{G}$ of $8.3 \%$ at $3070 \mathrm{rpm}$.

Brake thermal efficiency improved as the engine load increased, as shown in L1 and L2. It is because when the throttle body of motorcycle is largely open, the mixture of air and hydrogen compresses in the combustion chamber. The combustion of the air and fuel mixture will be increased because the fuel part is already blended with hydrogen, which is very sensitive to heat owing to the assistance of the technical properties of 
hydrogen, such as flammability, minimum ignition energy, auto ignition temperature and laminar flame speed at normal temperature and pressure [5]. During the resistance of vehicle movement at L1 test such as Figure 6 with the engine speed for both engines at $2460 \mathrm{RPM}$, the brake thermal efficiency for $\mathrm{G}+\mathrm{H}_{2}$ is $11 \%$ compared to that for $\mathrm{G}$ of $9 \%$, giving an increase of $22 \%$. The increase of $22 \%$ shows that the advantage of the application of hydrogen is to stabilise the stroke of the gasoline engine by reducing the energy loss factors, such as "fuel overflow", and the ability to reduce the existence of pollutant gases resulting from incomplete combustion.

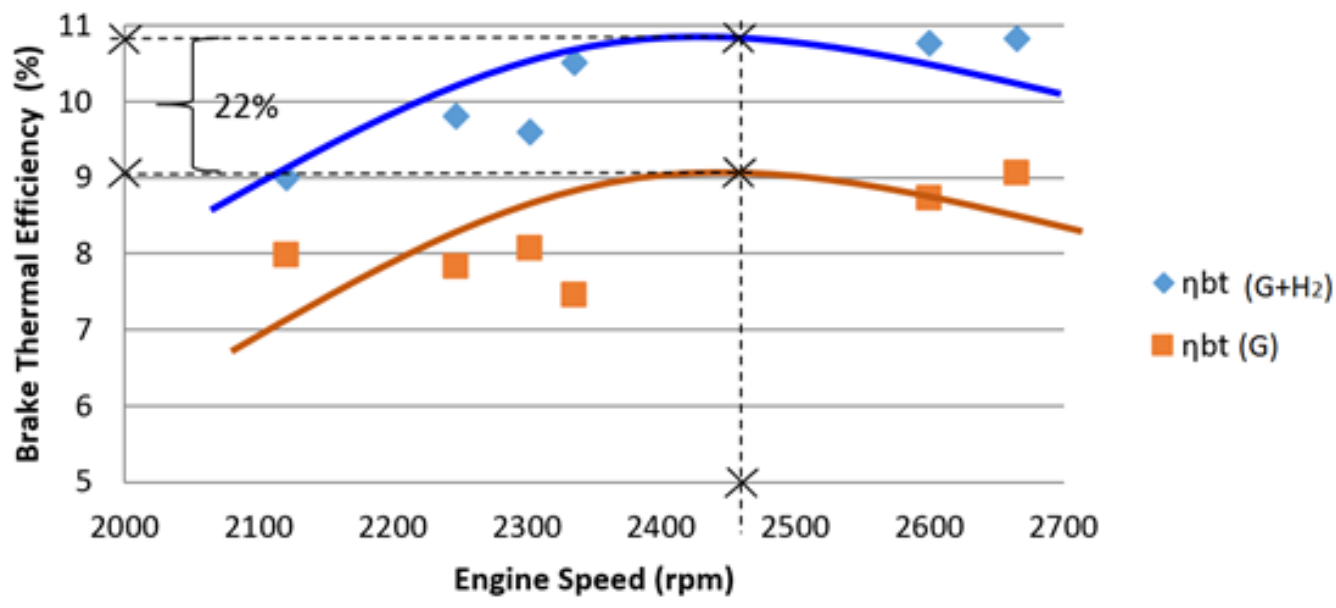

Figure 6. The differences of $\eta \mathrm{bt}$ for $\mathrm{G}+\mathrm{H} 2$ and $\mathrm{G}$ at test condition $\mathrm{L} 1$.

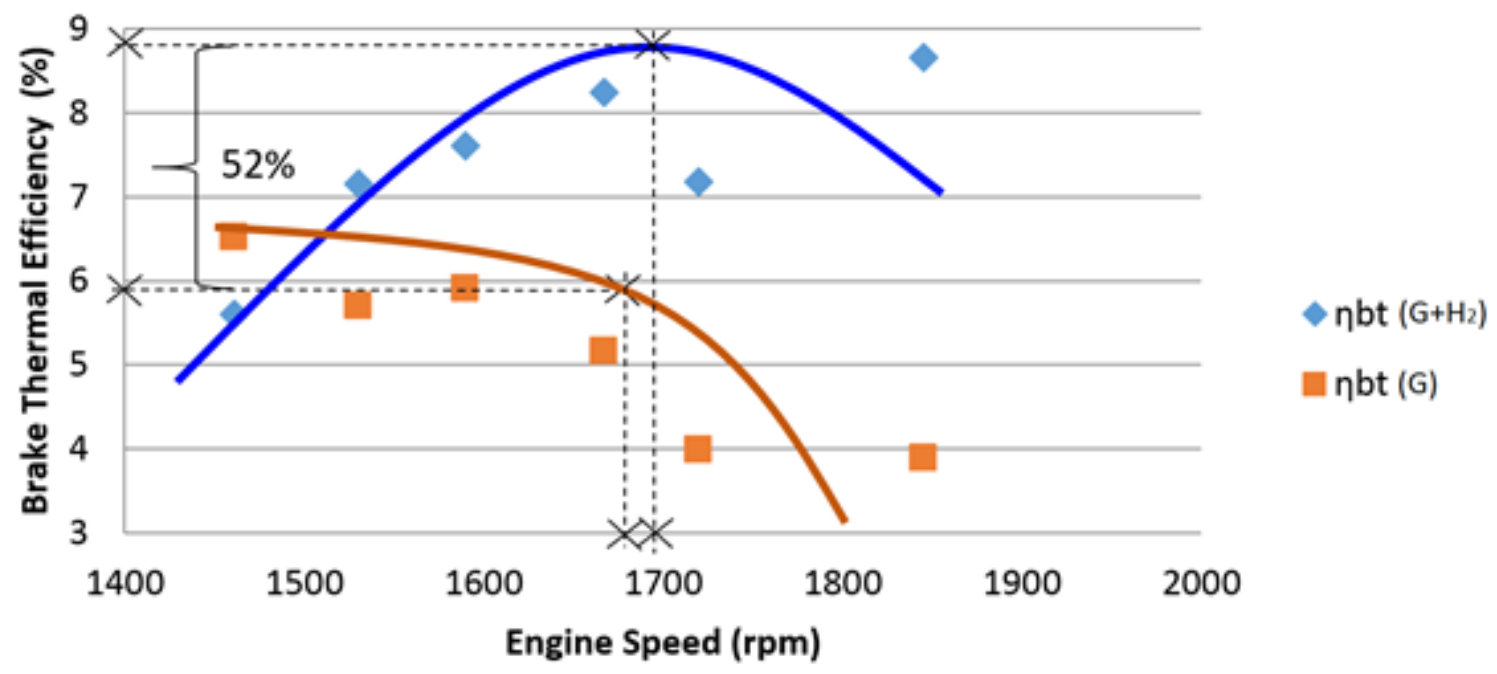

Figure 7. The differences of $\eta b t$ for $\mathrm{G}+\mathrm{H}_{2}$ and $\mathrm{G}$ at test condition $\mathrm{L} 2$.

The percentage of brake thermal efficiency continues to rise when the engine undergoes the L2 test, where significant differences of up to $52 \%$ can be seen in Figure 7. In this condition, the conventional motorcycle engine $(\mathrm{G})$ cannot sustain the efficiency of combustion because the fuel mixture is in a rich ratio. Thus, the combustion is not complete, unlike with $\mathrm{G}+\mathrm{H}_{2}$. This is because the thermal efficiency of the engine $(\mathrm{G})$ decreases drastically to be less than $6 \%$ and the engine rotational speed drops to 1700 $\mathrm{rpm}$. Technically, the mass flow rate $(\mathrm{mf})$ also increases, but the movement of the engine 
cycle (Ne) is still at low levels to maintain high torque so that the engine continues running without changing to a lower gear ratio. The overall thermal efficiency of the engine $(\mathrm{G})$ for L0, L1 and L2 is proportional at $7 \%$ compared to $8.61 \%$ for engine $(\mathrm{G}+$ $\mathrm{H}_{2}$ ).

\section{Hydrocarbon}

Table 5 and Figure 8 display the differences between the readings of hydrocarbons (ppm) on the test engine using gasoline mixed with hydrogen $\left(\mathrm{G}+\mathrm{H}_{2}\right)$ compared to just gasoline $(\mathrm{G})$. The content of $\mathrm{HC}$ emissions increased as the engine load increased. This is because hydrocarbon gases cannot be completely burned during the power stroke caused by a spark from the spark plug. One of the consequences of this is the occurrence of excessive fuel flow, which results in the proper oxidation of the gasoline fuel elements. Therefore, the engine requires full torque $(\mathrm{T})$ and high engine output (FO) against the burden imposed on it to stay moving. The opening of the throttle valve will force the engine revolutions ( $\mathrm{Ne}$ ) into maximum condition, but at the same time, as the load increases, the torque and output (FO) start to decrease owing to the movement of the piston. During the load test on L0, when the engine is in a linear motion, the performance of the engine with $\mathrm{G}+\mathrm{H}_{2}$ will increase and the total hydrocarbon content in the exhaust fumes reduced up to $58 \%$ compared to the normal operating engine $(\mathrm{G})$. When the testing of the engine increase to load L1 and L2, hydrocarbons content in the $\mathrm{G}+\mathrm{H}_{2}$ engine is $85 \mathrm{ppm}$ compared to $117 \mathrm{ppm}$ for G. After the last experiment at L2, a value of $95 \mathrm{ppm}$ hydrocarbon is still lower compared to that for engine $\mathrm{G}$ at $114 \mathrm{ppm}$. Overall, under the three conditions of testing (L0, L1, L2), the engine with $\mathrm{G}+\mathrm{H}_{2}$ showed reduced hydrocarbon content by $34 \%$ compared to the gasoline engine. The results show that the involvement of hydrogen in the stoichiometric mixture ratio can increase the quality of combustion and reduce the factor of energy losses via technical influences such as friction in the cylinder walls, rich/poor fuel mixtures and ignition failure (misfire).

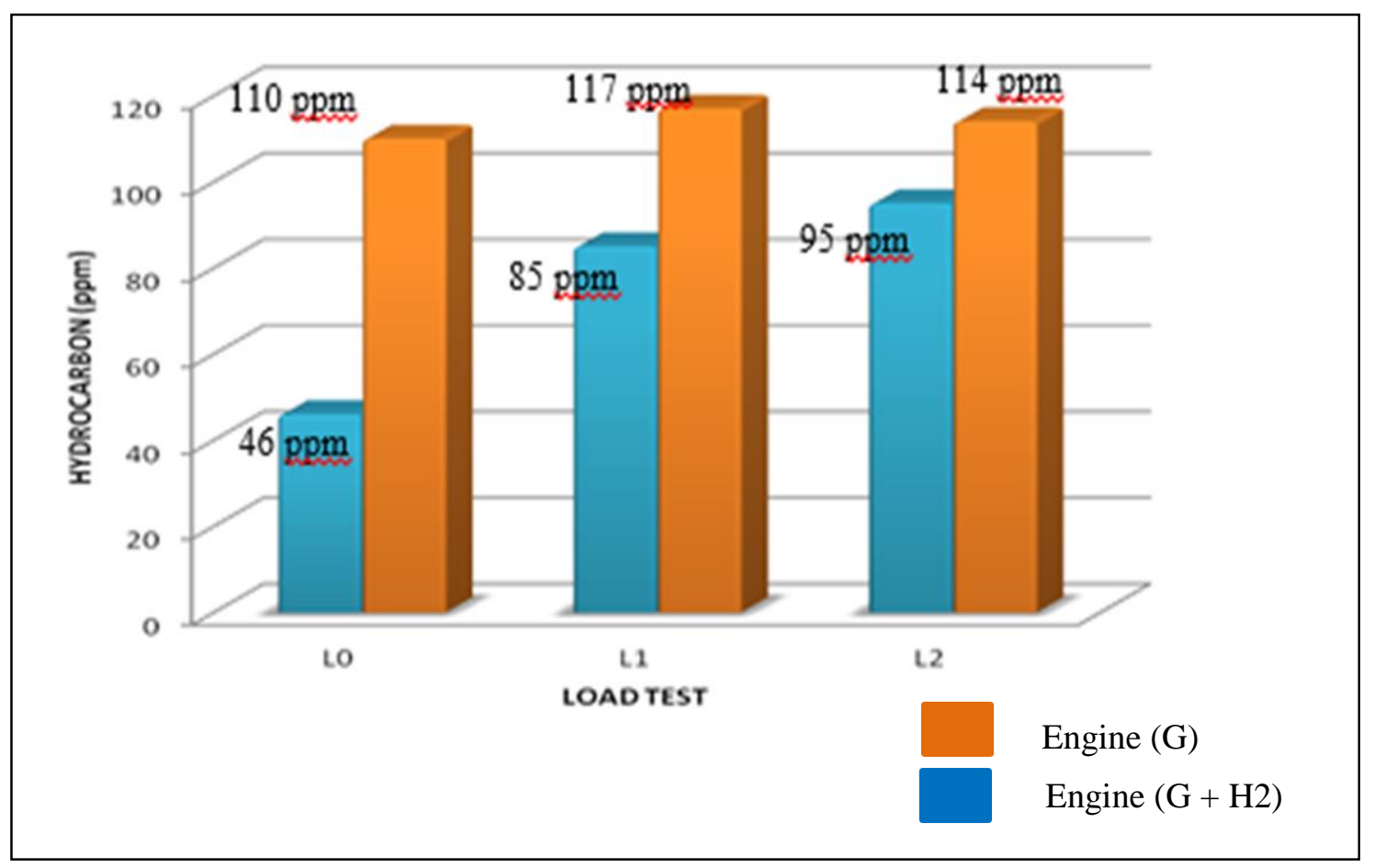

Figure 8. Hydrocarbon emissions produced for $\mathrm{G}+\mathrm{H}_{2}$ and $\mathrm{G}$ engines under load test L0, L1 and L2. 
Table 5. Hydrocarbon emissions produced for $\mathrm{G}+\mathrm{H}_{2}$ and $\mathrm{G}$ engines under load test $\mathrm{L} 0$, L1 and L2.

\begin{tabular}{cccc}
\hline Load test & \multicolumn{3}{c}{ Hydrocarbon } \\
\hline Testing level & $\begin{array}{l}\text { Gasoline }+\mathrm{H}_{2} \\
(\mathrm{ppm})\end{array}$ & Gasoline $(\mathrm{ppm})$ & Result $\pm(\%)$ \\
L0 & 46 & 110 & -58 \\
L1 & 85 & 117 & -27 \\
L2 & $\underline{95}$ & $\underline{114}$ & $\underline{-16.7}$ \\
Total & 75.3 & 113.6 & -33.9 \\
\hline
\end{tabular}

\section{Carbon Monoxide}

Table 6 and Figure 9 show carbon monoxide readings with the use of $\mathrm{G}+\mathrm{H}_{2}$ compared to the use of just gasoline in loading tests L0, L1 and L2. A decrease of $41.1 \% \mathrm{CO}$ for $\mathrm{G}$ $+\mathrm{H}_{2}$ compared to $\mathrm{G}$ during loading test LO proves that the involvement of hydrogen improves the combustion performance by helping complete combustion despite a lack of oxygen in the mixture for the oxidation of hydrocarbon fuels. When the workload increases, $\mathrm{G}+\mathrm{H}_{2}$ is still able to maintain the combustion performance improvement and a reduction of between $12.6 \%$ and $45 \%$ in the release of CO into the air compared to that for current gasoline engines. The overall reduction of $\mathrm{CO}$ in the exhaust gas is a $32.9 \%$ reduction for all engine operation conditions (L0, L1, L2). Table 6 shows that at test level $\mathrm{L} 0$, production of $\mathrm{CO}$ for $\mathrm{G}+\mathrm{H}_{2}$ can be reduced by $41.1 \%$ compared to $\mathrm{G}$, which is $3.45 \%$ for $\mathrm{G}+\mathrm{H}_{2}$ compared to $5.86 \%$ for $\mathrm{G}$ with the oxygen content at 15.97 and 11.70 , respectively. At load L1, the $\mathrm{CO}$ readings increased to $4.64 \%$ for $\mathrm{G}+\mathrm{H}_{2}$ and 5:31\% for $\mathrm{G}$ with oxygen readings of 11:49 compared to 12.63 at level $\mathrm{L} 0$. The percentage reduction of $\mathrm{CO}$ remains the same despite a $12.6 \%$ reduction of carbon monoxide. In the load test at $\mathrm{L} 2$, the reduction of $\mathrm{CO}$ emissions was $42.5 \%$ despite the declining performance of the engine as a result of the collapse of engine power. The poor performance shown by the engine with $\mathrm{G}$ during $\mathrm{L} 2$ shows that $\mathrm{CO}$ further increased to $6.26 \%$ against an increase of $5.31 \%$ under L1 load conditions. The situation is very different from the engine performance of $\mathrm{G}+\mathrm{H}_{2}$, especially while the engine in condition test on load $\mathrm{L} 2$, reducing the reading by $35 \%$ from the previous reading of $4.64 \%$ down to $3.43 \%\left(\mathrm{O}_{2}=7.75\right)(\mathrm{G}$ $\left.+\mathrm{H}_{2}\right) \mathrm{CO}$ content in the exhaust gases during engine performance start to declining.

Table 6. Hydrocarbon production for the $\mathrm{G}+\mathrm{H}_{2}$ and $\mathrm{G}$ engines through load tests $\mathrm{L} 0$, L1 and L2.

\begin{tabular}{cccccc}
\hline Load test & \multicolumn{5}{c}{ Carbon monoxide } \\
\hline Level of test & Gasoline $+\mathrm{H}_{2}$ & $\mathrm{O}_{2}$ ppm $(\mathrm{G}+$ & Gasoline & $\mathrm{O}_{2}$ ppm & Percentage \\
L0 & $(\%)$ & $\left.\mathrm{H}_{2}\right)$ & $(\%)$ & $(\mathrm{G})$ & $\pm(\%)$ \\
$\mathrm{L} 1$ & 3.45 & 15.97 & 5.86 & 11.70 & -41.1 \\
L2 & 4.64 & 11.49 & 5.31 & 12.63 & -12.6 \\
Total value & $\underline{3.43}$ & $\underline{7.75}$ & $\underline{6.26}$ & $\underline{11.43}$ & $\underline{-45.2}$ \\
\hline
\end{tabular}




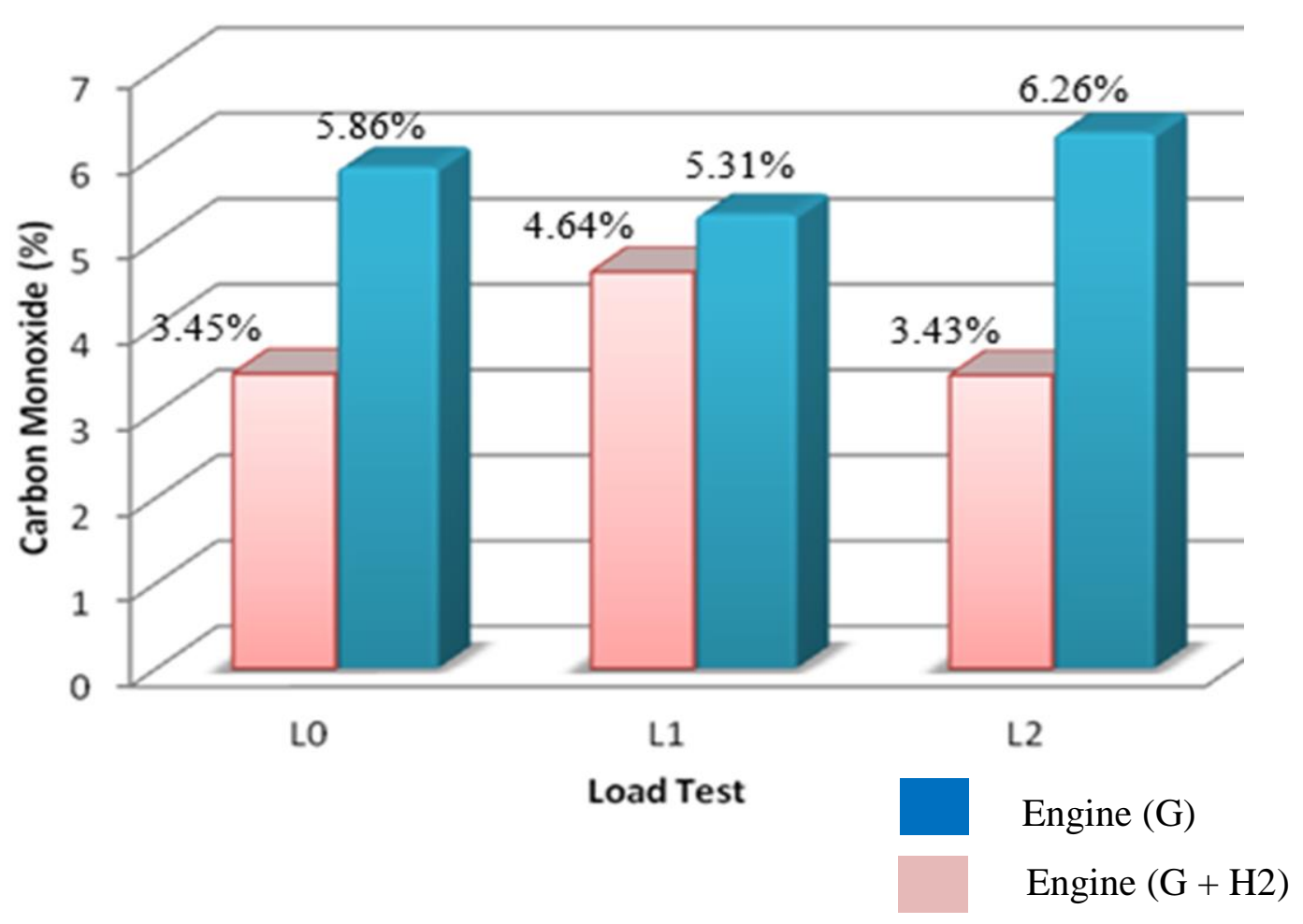

Figure 9. Hydrocarbon production for the $\mathrm{G}+\mathrm{H}_{2}$ and $\mathrm{G}$ engines through load tests $\mathrm{L} 0$, L1 and L2.

\section{CONCLUSIONS}

This study shows that hydrogen can influence the brake thermal efficiency by increasing engine performance, as well as reducing emissions of hydrocarbon and carbon monoxide. The technical implications of heat loss and energy improvement with the addition of hydrogen as a supplement fuel have a good impact on the brake thermal efficiency and emissions, especially for conventional engines. The average brake thermal efficiency performance is $23 \%$ higher than that for a gasoline-only engine and is better with the use of hydrogen as a supplemental fuel at the minimum rate of $4 \%$. The total hydrocarbon production for the three loading conditions L0, L1 and L2 of $\mathrm{G}+\mathrm{H}_{2}$ was $34 \%$ better than using $\mathrm{G}$ only. Average hydrocarbon gas readings of $\mathrm{G}+\mathrm{H}_{2}$ during $\mathrm{L} 0, \mathrm{~L} 1$ and $\mathrm{L} 2$ testing decreased by $58.2 \%, 27.4 \%$ and $16.7 \%$ corresponding to readings of $46 \mathrm{ppm}, 85 \mathrm{ppm}$ and $95 \mathrm{ppm}$ as compared to those for $\mathrm{G}$ of $110 \mathrm{ppm}, 117 \mathrm{ppm}$ and $114 \mathrm{ppm}$. The 33\% reduction of $\mathrm{CO}$ on average in the experiments showed that hydrogen as a supplementary fuel in with gasoline and air can help the combustion process, especially if the oxygen content in air and fuel mixture is not sufficient. Hopefully, the success of this study in reducing emissions of $\mathrm{HC}$ and $\mathrm{CO}$ whilst increasing engine performance will spark the interest of readers and researchers to further investigate and explore the use of hydrogen as comparable to other sources of conventional fuels and develop this technology on an ongoing basis so that this technology can benefit the global community. 


\section{ACKNOWLEDGEMENTS}

All related proceedings of this survey, comments, and guidance are supported by the SERI (Solar Energy Research Institute). The authors would like to thank the National University of Malaysia, Bangi, Selangor Malaysia (UKM) for providing laboratory facilities and financial assistance under project No. GGPM-2014-017

\section{REFERENCES}

[1] Ong HC, Mahlia TMI, Masjuki HH. A review on energy pattern and policy for transportation sector in Malaysia. Renewable and Sustainable Energy Reviews. 2012;16:532-42.

[2] Yamin JAA, Gupta HN, Bansal BB, Srivastava ON. Effect of combustion duration on the performance and emission characteristics of a spark ignition engine using hydrogen as a fuel. International Journal of Hydrogen Energy. 2000;25:581-9.

[3] Sáinz D, Diéguez PM, Urroz JC, Sopena C, Guelbenzu E, Pérez-Ezcurdia A, et al. Conversion of a gasoline engine-generator set to a bi-fuel (hydrogen/gasoline) electronic fuel-injected power unit. International Journal of Hydrogen Energy. 2011;36:13781-92.

[4] Akif Ceviz M, Sen AK, Küleri AK, Volkan Öner İ. Engine performance, exhaust emissions, and cyclic variations in a lean-burn SI engine fueled by gasolinehydrogen blends. Applied Thermal Engineering. 2012;36:314-24.

[5] Don Karner JF. Hydrogen/CNG blended fuels performance testing in a Ford F150. US Department of Energy Freedom Car \& Vehicle Technologies Program; 2003.

[6] Escalante Soberanis MA, Fernandez AM. A review on the technical adaptations for internal combustion engines to operate with gas/hydrogen mixtures. International Journal of Hydrogen Energy. 2010;35:12134-40.

[7] Wang S, Ji C, Zhang J, Zhang B. Comparison of the performance of a sparkignited gasoline engine blended with hydrogen and hydrogen-oxygen mixtures. Energy. 2011;36:5832-7.

[8] Bortnikov LN. Combustion of a gasoline-hydrogen-air mixture in a reciprocating internal combustion engine cylinder and determining the optimum gasolinehydrogen ratio. Combustion, Explosion, and Shock Waves. 2007;43:378-83.

[9] Migun AN, Chernukho AP, Zhdanok SA. Influence of the addition of hydrogen and of a synthesis gas on the characteristics of the process of combustion of gasoline-air mixtures under conditions typical of internal combustion engines. Journal of Engineering Physics and Thermophysics. 2006;79:651-6.

[10] D'Andrea T, Henshaw PF, Ting DSK. The addition of hydrogen to a gasolinefuelled SI engine. International Journal of Hydrogen Energy. 2004;29:1541-52.

[11] Bari S, Mohammad Esmaeil M. Effect of $\mathrm{H} 2 / \mathrm{O} 2$ addition in increasing the thermal efficiency of a diesel engine. Fuel. 2010;89:378-83.

[12] Lluis Soler JM, Munoz M, Casado J. Aluminium and Aluminium alloy as sources of hydrogen for fuel cell application Journal of Power Sources 2007;169:6.

[13] Demirci UB, Akdim O, Miele P. Aluminum chloride for accelerating hydrogen generation from sodium borohydride. Journal of Power Sources. 2009;192:310-5.

[14] Olivares-Ramírez JM, Castellanos RH, Marroquín de Jesús Á, Borja-Arco E, Pless RC. Design and development of a refrigeration system energized with 
hydrogen produced from scrap aluminum. International Journal of Hydrogen Energy. 2008;33:2620-6.

[15] Franzoni F, Milani M, Montorsi L, Golovitchev V. Combined hydrogen production and power generation from aluminum combustion with water: Analysis of the concept. International Journal of Hydrogen Energy. 2010;35:1548-59.

[16] Alinejad B, Mahmoodi K. A novel method for generating hydrogen by hydrolysis of highly activated aluminum nanoparticles in pure water. International Journal of Hydrogen Energy. 2009;34:7934-8.

[17] Ji C, Wang S. Effect of hydrogen addition on combustion and emissions performance of a spark ignition gasoline engine at lean conditions. International Journal of Hydrogen Energy. 2009;34:7823-34.

[18] Ji C, Wang S. Experimental study on combustion and emissions performance of a hybrid hydrogen-gasoline engine at lean burn limits. International Journal of Hydrogen Energy. 2010;35:1453-62.

[19] Sadiq Al-Baghdadi MA-R, Shahad Al-Janabi HA-K. Improvement of performance and reduction of pollutant emission of a four stroke spark ignition engine fueled with hydrogen-gasoline fuel mixture. Energy Conversion and Management. 2000;41:77-91.

[20] Ji C, Wang S. Strategies for improving the idle performance of a spark-ignited gasoline engine. International Journal of Hydrogen Energy. 2012;37:3938-44.

[21] Paul A, Bose PK, Panua R, Debroy D. Study of performance and emission characteristics of a single cylinder CI engine using diethyl ether and ethanol blends. Journal of the Energy Institute. 2015;88:1-10.

[22] Bose PK, Banerjee R. An experimental investigation on the role of hydrogen in the emission reduction and performance trade-off studies in an existing diesel engine operating in dual fuel mode under exhaust gas recirculation. Journal of Energy Resources Technology. 2012;134:012601. 